\title{
Wittgenstein and Levinas on the Transcendentality of Ethics
}

\section{Appelqvist, Hanne}

Routledge

2020

Appelqvist , H \& Pöykkö , P-M 2020 , Wittgenstein and Levinas on the Transcendentality of Ethics . in H Appelqvist (ed.) , Wittgenstein and the Limits of Language . Routledge Studies in Twentieth-Century Philosophy, Routledge , New York, pp. 65-89.

http://hdl.handle.net/10138/330242

unspecified

acceptedVersion

Downloaded from Helda, University of Helsinki institutional repository.

This is an electronic reprint of the original article.

This reprint may differ from the original in pagination and typographic detail.

Please cite the original version. 
Authors' manuscript. Final version published in Hanne Appelqvist (ed.) Wittgenstein and the Limits of Language, Routledge 2020, pp. 65-89.

\section{Wittgenstein and Levinas on the Transcendentality of Ethics}

\section{Hanne Appelqvist \& Panu-Matti Pöykkö}

"Feeling the world as a limited whole - it is this that is mystical" (TLP 6.45).

"The conditions for the world as a whole should not be confounded with the laws regulating things inside the world" (Levinas 2008, 93).

\footnotetext{
Abstract

This article discusses Wittgenstein's early ethics by comparing it with the ethical thought of Emmanuel Levinas. By treating ethics as transcendental, both Wittgenstein and Levinas are responding to the tension they find between contingent facts of the world and the absolute demand of ethics. We argue that the origin of this tension may be traced back to Kant's philosophy, specifically to Kant's division between nature and morality. Instead of grounding the ethical in the world of facts or in a transcendent realm over and above the limits of the world,
} 
both Wittgenstein and Levinas resolve the tension by appealing to the idea of a perspective, distinct from the perspective of knowledge, that shows the world as meaningful or purposive in spite of its objective lack of meaning. By spelling out the relevant similarities and differences between Wittgenstein and Levinas, the paper addresses the nature and extent of the Kantianism in Wittgenstein's early ethics.

Keywords: early Wittgenstein, Levinas, Kant, ethics, aesthetics, reflecting judgment, world as a whole, the other, transcendental subject, sub specie aeternitatis, God.

\section{Introduction: The Gulf}

According to Kant, the domain of nature and the domain of freedom are separated from one another by an "incalculable gulf" (CPJ 5:176). Nature is determined by laws of nature and is the proper object of empirical knowledge. The domain of freedom, by contrast, is governed by the moral law, which is the a priori principle constitutive of pure practical reason, independent of the empirical domain. From the perspective of theoretical reason, nature remains a mere mechanistic aggregate of facts, where no empirical intuition corresponding to freedom, presupposed by morality, can be found. Hence, Kant claims, while we can think about freedom, we cannot have knowledge of it. This is because knowledge, in the strict sense of the First Critique, requires both concepts and empirical content. (CPR xxviii; CPR A545-547.)

However, the human being is capable of thinking of herself not only as an empirical creature subject to natural laws, but also as the legislator of her own ends ( $\mathrm{G}$ 4:412). These ends are answerable to the moral law, which the subject finds in her own practical reason as the 
necessary condition of agency (G 4:429, CPrR 5:29). ${ }^{1}$ Moreover, the absolute demand of the moral law leads one to expect that nature itself may be hospitable to our moral ends even if nothing in nature as the object of knowledge suggests that this is possible. Accordingly, Kant's goal is to build a bridge between the domains of nature and freedom. For Kant, this amounts to the task of showing that we have the right to judge the world to be purposive for our moral goals even if that judgment fails to meet the requirements of cognition (CPJ 5:176).

This paper begins from the assumption that this Kantian picture of the place of the human being as an object of empirical knowledge and as the subject of moral agency is the immediate background of thought for both the early Wittgenstein and Levinas. ${ }^{2}$ Both assume that the world of facts is contingent, while the ethical demand is absolute - a position which immediately gives rise to the question of the grounds of that demand. Both respond to the question by stating that ethics is transcendental. Instead of grounding the absolute demand of morality on empirical facts, including psychological facts, they claim that ethics is a "condition of the world" (NB, 773; Levinas 1969, 204, 212). In this paper, we address the question of how this statement ought to be understood. We will argue that, just as the stage-setting of the problem, the solutions provided by Wittgenstein and Levinas respectively reflect the influence of Kant's philosophy, yet go beyond the view Kant himself prefers. ${ }^{4}$

\section{Wittgenstein: the world as pictured and as felt}

In the Tractatus, Wittgenstein defines the world as the "totality of facts" (TLP 1.1). These facts are contingent, devoid of value, and independent of the subject's will (TLP 6.41, 6.373). In these respects, Wittgenstein account of the world resembles Kant's domain of nature taken as the object of empirical knowledge. However, while Kant grants that we can conceptually formulate 
the moral law that is the a priori principle grounding the good will, Wittgenstein denies this possibility. According to him, "It is impossible to speak about the will in so far as it is the subject of ethical attributes. And the will as a phenomenon is of interest only to psychology." (TLP 6.423.) Moreover, given that no contingent fact as a possible content of a meaningful proposition has value, "it is impossible for there to be propositions of ethics" (TLP 6.42).

One of the paradoxical features of Wittgenstein's early philosophy is that, in spite of his denial of value-laden facts and ethical propositions, Wittgenstein does not abandon the distinction between good and bad willing. In the Notebooks, he mentions the good and bad will of the subject as one of his unquestionable starting points when addressing the question about the purpose of life (NB, 73; see TLP 6.43). While the picture theory of meaning entails the impossibility of meaningfully talking about the purpose of life, moral obligation, or the good will, the experience of one's life as meaningful and of an absolute ethical demand are not illusions for Wittgenstein (see Moore 2013, 521-253). Like the inexpressible logical form, which is the necessary condition for the possibility of sense, ethics is strictly ineffable (TLP 2.18, 6.13, 6.42). But for Wittgenstein, this ineffability just reflects the status of ethics as transcendental rather than empirical (TLP 6.421).

What we are suggesting, then, is that Wittgenstein's Tractatus may be read as incorporating a radicalized version of Kant's demarcation between the domains of nature and freedom. For Wittgenstein, the relevant contrast lies between the world of contingent facts on the one hand and the "sense" [Sinn] or "purpose" [Zweck] of that world on the other (TLP 1.1, 6.41; NB, 72-73). He writes: 
The sense of the world must lie outside the world. In the world everything is as it is, and everything happens as it does happen: in it no value exists - and if it did exist, it would have no value.

If there is any value that has value, it must lie outside the whole sphere of what happens and is the case. For all that happens and is the case is accidental. (TLP 6.41.)

Introducing the notions of value and sense of the world, these words also bear an echo of the opening lines of the Tractatus, where Wittgenstein defines the world as "all that is the case", determined by "the totality of facts" (TLP 1, 1.1). What is typically treated as the main import of the Tractatus, namely, the picture theory of language, treats the possibility of picturing such facts. According to this account, meaningful propositions are pictures of possible states of affairs, where true propositions correspond to existing states of affairs, namely, facts. Hence, every meaningful proposition has empirical content (TLP 2.12, 4.5). ${ }^{5}$ As argued by Erik Stenius and A. W. Moore, the Tractarian limits of meaningful language may in this respect be compared with the limits that Kant draws for cognition that presupposes sensible intuitions as well as concepts (Stenius 1960, 214-226; Moore 2013, 250-250 and Moore in this volume; CPR B75).

Like Kant, Wittgenstein, takes the world of facts to be the object of empirical inquiry. According to him, "the totality of true propositions is the whole of natural science" (TLP 4.11). Moreover, he claims, "the proper method of philosophy would really be the following: to say nothing except what can be said, i.e., propositions of natural science" (TLP 6.53). As the sense of the world lies "outside the world", it cannot be found among the accidental facts of the world, nor treated by philosophy insofar as we adopt what Wittgenstein claims to be its proper method (TLP 6.41). Yet, Wittgenstein adds paradoxically that natural science is "something that has 
nothing to do with philosophy" (TLP 6.53; see TLP 4.111). And he famously claims that the propositions of the Tractatus ought to be recognized as nonsensical by anyone who understands him (TLP 6.54). Hence, if philosophy is understood in the broader sense suggested by these remarks and as employed by Wittgenstein himself, then the problem of the sense of the world, while nonsensical by the lights of the picture theory of meaning, assumes a different role in the context of Wittgenstein's early thought.

As suggested by TLP 6.54 , the picture theory of meaning itself can hardly be taken to consist of statements of facts. Expressing the key idea of this theory, Wittgenstein writes, "What any picture, of whatever form, must have in common with reality, in order to be able to depict it - correctly or incorrectly - in any way at all, is logical form, i.e., the form of reality" (TLP 2.18). But logical form is not a fact or a collection thereof: as indicated by TLP 2.18 , it is a condition for picturing. Accordingly, it cannot be expressed in language: "Propositions cannot represent logical form: it is mirrored in them" (TLP 4.121). As we do not have access to a viewpoint outside of language or thought, logical form is known "from within", as the form constitutive of the possibility of thought, manifest or displayed in it (TLP, 3; TLP 2.172). This view is expressed later in the book by the following words: "Logic is not a body of doctrine, but a mirror-image of the world. Logic is transcendental" (TLP 6.13).

A point often left without explanation is that, in the Tractatus, Wittgenstein uses the notion of transcendentality to characterize ethics as well as logic (TLP 4.121, 6.421). In his 1916 Notebooks, Wittgenstein expresses the connection in a Kantian fashion, in terms of conditions. He writes: "Ethics does no treat of the world. Ethics must be a condition of the world, like logic.” (NB, 77.) The Kantian interpretation of the Tractatus typically understands Wittgenstein's statement of logic as a condition of the world as follows. Without the logical 
forms of objects as the constituents of facts, the facts themselves would fail to have structure, which Wittgenstein takes to be essential for something to be a fact (TLP 2.03-2.033). The same holds for propositions and thoughts that are also facts (TLP 2.141, 3, 3.14-3.141). Finally, without logical form propositions would fail to picture facts, given that a shared form between the picture and the pictured is a necessary condition for picturing (TLP 2.18, 4.06). In fact, like Kant's pure concepts of understanding that have an a priori relation with the objects of the phenomenal world, thought and reality are, in the Tractatus, claimed to have an a priori relation (TLP 3.02, 4.122, 5.4731; cf. CPR A80). ${ }^{6}$ But for Wittgenstein, thoughts always have the general form of "This is how things stand"; and how things stand is contingent and hence irrelevant for ethics (TLP 4.5, 6.41). How, then, should we understand Wittgenstein's claim of ethics as transcendental? How could ethics condition the world of contingent facts so that the world appears as having sense?

Restating the irrelevance of facts for ethics, Wittgenstein writes, "We feel that even when all possible scientific questions have been answered, the problems of life remain completely untouched" (TLP 6.52). In this remark, expressed by Wittgenstein by reference to a feeling, the problems of life indicate the sense of the world or - what Wittgenstein claims to be the same - the sense of life (NB, 73; TLP 5.621). ${ }^{7}$ In this context, the term "sense" does not indicate "what a picture represents" as it does in the case of pictures (including propositions), but is better understood as the meaning of life or the world seen as valuable (TLP 2.221). In the Notebooks, Wittgenstein uses the term "purpose" interchangeably with "sense", opening the relevant discussion by asking "What do I know about God and the purpose of life?" (NB, 72). ${ }^{8}$ A little short of a month later he writes: "To believe in God means to understand the question about the sense of life" (NB, 74). Combining these remarks with the Tractatus's point about the sense 
of the world lying outside the world, one might draw the conclusion that Wittgenstein's proposed answer to the problem of life is religious faith. That the case is less straightforward is shown by Wittgenstein's further remarks, according to which God is simply another name for the sense of the world, that "to believe in God means to see that the facts of the world are not the end of the matter", and that "to believe in God means to see that life has a sense" (NB, 73-74). Rather than religious faith traditionally conceived, the import of these remarks is a repeated confirmation that the factual perspective on the world, substantiated by the picture theory of meaning, is not exclusive.

In the Tractatus, Wittgenstein connects the problem of life to ethics, aesthetics, and religion, i.e., those fields of traditional philosophy that in Kant's account fall outside the bounds of theoretical philosophy. However, by contrast to Kant who only denies the possibility of cognition of freedom and eternity, Wittgenstein denies the very sensicality of propositions or thoughts about value (CPR A254-255, B xxv-xxix; TLP 4.023, 4.06; see Moore 2013). Instead, the term he typically uses in the context of value is "feeling" (see, e.g., TLP 6.43, 6.45; NB, 74, 86; LE 7-8). The difference between Kant and Wittgenstein boils down to Wittgenstein's rejection of any expressible a priori, manifest in his treatment of logic as well as ethics. While Kant's position still allows the conceptual formulation of pure concepts of understanding that ground the possibility of empirical cognition, for Wittgenstein, logical form as the condition of sense is strictly ineffable and only shows itself (TLP 2.172, 4.121). The same ineffability applies to ethics: for Kant the moral law as the a priori principle of practical reason is expressible by the different formulations of the categorical imperative, whereas Wittgenstein states that "It is clear that ethics cannot be put into words. Ethics is transcendental." (TLP 6.421.) And yet, he writes, 
"There are, indeed, things that cannot be put into words. They make themselves manifest. They are what is mystical." (TLP 6.522.)

The reason for Wittgenstein's denial of ethical propositions is twofold. First, he limits the realm of meaningful language and thought to the picturing of contingent facts. Second, he holds that by contrast to contingent facts ethics is absolute. In accordance with Kant, who argues that the moral law must exhibit apodictic necessity, i.e., the kind of normative force that resides in the mere form of the principle independently of empirical considerations, Wittgenstein claims that ethics cannot be grounded on anything contingent (TLP 6.41). In his 1929 "Lecture on Ethics", Wittgenstein states: "No state of affairs has, in itself, [...] the coersive power of an absolute judge" (LE, 7). The suggestion clearly is that ethics ought to have such a power. Wittgenstein illustrates the point by comparing relative value statements, reducible to facts, to a road that will lead to an arbitrarily predetermined end. Should one reject the end, there would be no point in using the road. But an absolute value judgment ought to determine "the absolutely right road", "the road which everybody on seeing it would, with logical necessity, have to go, or be ashamed for not going" (LE, 7). The road itself would, as it were, present its necessity with an absolute normative force that is self-evident. ${ }^{9}$

In the Tractatus, Wittgenstein writes: "When an ethical law of the form, 'Thou shalt...' is laid down, one's first thought is, 'And what if I do not do it?' It is clear, however, that ethics has nothing to do with punishment and reward in the usual sense of the terms." (TLP 6.422). In the usual sense of the terms, rewards and punishments are factual events. Hence, explaining the normative force of the ethical demand by reference to them will fail to meet the absoluteness or “fundamentality" Wittgenstein attaches to ethics (see NB, 79). In 1929, Wittgenstein states that he can express his feeling of ethics only by a metaphor, namely, that "if a man could write a 
book on Ethics which really was a book on Ethics, this book would, with an explosion, destroy all the other books in the world" (LE, 7). It seems, then, that if there were ethical laws, these would have to exhibit the kind of necessity that Kant attributes to the categorical imperative. However, for Wittgenstein, no meaningful proposition is true a priori; and the only propositions that are necessarily true, namely tautologies, are true only in virtue of saying nothing about reality (TLP $2.225,4.461,6.375$ ). This means that, by contrast to Kant whose categorical imperative is capable of determining which empirical actions are in conformity with the moral law, Wittgenstein's insistence on the inexpressibility of ethics effectively blocks any connection between ethics and specific states of affairs. For Wittgenstein, "the only necessity that exists is logical necessity", and that will not help us in uncovering the "coersive power" of ethics (TLP 6.375; LE, 7).

Nevertheless, we believe that Wittgenstein's alignment of ethics with logic as "conditions of the world" ought to be taken seriously, as it points to the best available model for understanding transcendentality of ethics (NB, 79; TLP 6.13, 6.421). In our reading, the operative notion of transcendentality is Kantian in both cases, indicating the necessary conditions for the possibility of kinds of judgment and also, arguably, evoking a connection to the metaphysical subject as the seat of those conditions. To be sure, the source of logical form necessary for the possibility of picturing is subject to scholarly debate. Some take it to originate in reality, i.e., in the forms of objects, which Wittgenstein claims to be the unalterable substance of the world (TLP 2.021ff.; Hacker 1986, 23n; Pears 1987, 8; Glock 1997, 296). Others reject the very question as misguided, arguing that Wittgenstein's goal is to disarm any attempt to justify the formal relation between thought and the world (Sullivan 1996). The Kantian interpretations of the Tractatus that draw their inspiration from Erik Stenius's 1960 commentary typically lean 
towards the idealist answer: the origin of logical form that guarantees the formal unity of thought and reality, is the metaphysical subject (TLP 5.63-5.633). It is not only that it would be difficult to explain logical necessity by reference to contingent facts of the world. The Kantian interpretation is further supported by Wittgenstein's insistence on the impossibility of illogical thought, which is a natural outcome if the form of thought precedes the form of reality (TLP 5.4731, 3.02; see Kannisto 1986, 148-153).

Granted, Wittgenstein argues that, when understood in factual terms, there is no such unified entity that we could rightfully call a "subject". The empirical subject is just an aggregate of facts and, Wittgenstein claims, "a composite soul would no longer be a soul" (TLP 5.5421). Whatever subject empirical investigation may uncover, it fails to do the philosophical work of making thoughts the subject's own (TLP 5.542). However, like Kant who rejects the Cartesian conception of the self but proceeds by introducing the idea of a formal, transcendental subject, to whom the phenomenal world is given and who is somehow responsible for the unity of that world, Wittgenstein writes:

Thus there really is a sense in which philosophy can talk about the self in a nonpsychological way.

What brings the self into philosophy is the fact that "the world is my world".

The philosophical self is not the human being, not the human body, or the human soul, with which psychology deals, but rather the metaphysical subject, the limit of the world - not a part of it. (TLP 5.641.) 
Wittgenstein's identification of the metaphysical subject with the limit of the world means that the subject cannot be isolated by means of empirical investigation any more than logical form can. In the Notebooks, Wittgenstein describes the subject as a "presupposition" [Voraussetzung] of the existence of the world, thereby aligning the subject with the other two "conditions of the world", ethics and logic (NB, 79). If read through the lens of Kant's philosophy, the philosophical self is the vehicle of the world's unity, displayed in the forms of thought and in the forms of facts - a view suggested by Wittgenstein's claim about the world being "my world" as the origin of the very notion of a metaphysical subject (TLP 5.641; see CPR B131-136).

Now, the only role for the metaphysical subject in its "theoretical capacity", as we would like to call it, seems to be to "picture facts". The metaphysical subject "shrinks to point without extension, and there remains the reality co-ordinated with it" (TLP 5.64). It thus looks as if the subject were nothing but a passive mirror of evaluatively neutral facts, inviting the interpretation of the metaphysical subject as equal with logical form (Kannisto 1986, 150). If this were the exclusive role of the metaphysical subject in Wittgenstein's early view, then the inexpressibility or ethics would amount to denial of value. Voicing the concern in 1916, Wittgenstein writes, "can we conceive of a being that isn't capable of Will at all, but only of Idea (of seeing for example)? In some sense this seems impossible. But if it were possible then there could also be a world without ethics." $(\mathrm{NB}, 77 .)^{10}$

However, and again in accordance with Kant's position, the metaphysical self does not encounter the world solely from the perspective of meaningful thought. The subject is also a willing subject, and this is what renders the world meaningful or purposive. Wittgenstein writes: "If the will did not exist, neither would there be that centre of the world, which we call the I, and which is the bearer of ethics. What is good and evil is essentially the I, not the world." (NB, 80.) 
Hence, whatever the correct view on the source of logical form may be, Wittgenstein is quite explicit about the relation between the metaphysical subject and ethics: "Good and evil only enter through the subject. And the subject is not part of the world, but a boundary of the world." (NB, 79; see Moore 1987, 132.)

But how are we to distinguish between the good and the evil, if the facts of the world are devoid of value and the denial of conceptually expressible ethical principles has blocked even the possibility of a conformity between the moral demand and certain empirical actions still available for Kant? Besides, if the willing subject is not a part of the world, then how can it interact with that world - a difficulty for Kant as well (see CPJ 5:176)? Wittgenstein, clearly aware of this problem, bites the bullet. He writes: "The world is independent of my will" (TLP 6.373). And continues: "Even if all we wish for were to happen, still this would only be a favour granted by fate, so to speak: for there is no logical connexion between the will and the world, which would guarantee it, and the supposed physical connexion itself is surely not something that we could will" (TLP 6.374).

Interestingly, Wittgenstein's initial response to the question of the subject's interaction with the world evokes the notion of the limit of the world. While the will is impotent with respect to facts, Wittgenstein claims that there is a difference in the world corresponding to the good or evil will, manifest in a shift in the limits of the world and experienced as happiness or unhappiness:

If the good or bad exercise of the will does alter the world, it can alter only the limits of the world, not the facts - not what can be expressed by means of language. 
In short the effect must be that it becomes an altogether different world. It must, so to speak, wax and wane as a whole.

The world of the happy man is different from that of the unhappy man. (TLP 6.43.)

This remark should not be understood as claiming that ethics is a matter of feeling happy in the empirical sense of the term. Psychological states are, for Wittgenstein, as insignificant for ethics as any other facts (LE, 6). The happiness Wittgenstein talks about is rather a state of "agreement" or "harmony" between the transcendental will and the world: "In order to live happily I must be in agreement with the world. And that is what 'being happy' means" (NB, 75; see NB 78). The agreement between the will and the world is brought about by the subject's attitude to that world and manifests in a change in the limits of the world (NB, 78). ${ }^{11}$ But the question remains, if the grounds for the harmony between the will and the world cannot be found in the world nor expressed conceptually, then whence does the absolute demand of morality derive its force?

While his rejection of conceptually expressible ethical principles distances his position from Kant's moral philosophy, in our view Wittgenstein's way of treating ethics as absolute and transcendental still draws on Kant's core idea of locating the foundation of ethics in an a priori principle. In Kant's account, the goodness of the will means that the will, i.e., pure practical reason, is determined solely by its own a priori principle revealed by transcendental reflection of the necessary condition for the possibility of practical deliberation. Our proposal is that, in accordance with this strategy, Wittgenstein treats ethics as transcendental - and as such on a par with logic - but as grounding a perspective on the world that is distinct from the perspective grounded by logic. However, while logical form is given to us as the a priori form of our 
thought, the perspective of ethics is grounded in an a priori form of feeling. The perspective of ethics shows the world as a happy world by bringing the will into a harmony with the otherwise evaluatively neutral facts; it shows the world as having sense or purpose that arises from the $a$ priori form of willing itself.

\section{Levinas: The Other as an Object and as an Absolute}

The Kantian tension between contingent facts and the absolute ethical demand, which in our reading motivates Wittgenstein's early ethics, is similarly at work in Emmanuel Levinas's philosophy. Levinas joins Wittgenstein in thinking that life acquires sense or value only against the ethical demand. In Autrement qu'ètre ou au-delà de l'essence, Levinas writes:

"Responsibility is what first enables one to catch sight of and conceive of value" (Levinas 1991, 128). By "value" or "the ethical", Levinas does not refer to moral, aesthetic, religious, and other evaluative judgments, which he takes to depend on their historical and cultural contexts. By contrast, the ethical is that which gives meaning to our engagement with the world and grounds specific evaluative judgments.

In striking parallel with Wittgenstein's way of connecting ethics with the sense of life and expressing that connection by reference to God (NB, 72-74), Levinas writes:

Sense is the very fact that being is oriented, that there is Action or Life. Sense is the sense of life. To have sense is to be related to that which gives sense to life. What gives sense to life is above life. To be above life is what makes the whole of life oriented towards the other [lui]. To be oriented $=$ to act and to reach [agir et aboutir] (it is not a game). To be completely oriented is to act without seeking simultaneity with the act's 
success (seeking simultaneity with the act's success is not to be oriented). That towards which being is absolutely oriented $=$ the Infinite $[\ldots]$. But God is unrevealed - in order for the renunciation of recompense not to be compromised. Sense demands simultaneously that action's success is guaranteed but that all recompense - all simultaneity - is denied. Hence it demands a God that is not revealed or is revealed in ingratitude: the face of the Other [Autrui]. (Levinas 2009, 3, translation by Pöykkö.)

This passage plays with the double meaning of the French word sens which, like the German Sinn, means both sense and direction or orientation. Ethics gives sense to life, but also orients me towards the other who commands me to acknowledge her uniqueness and vulnerability, to respond for and to her. At the outset, Levinas's emphasis on the other marks a grave difference between him and Wittgenstein. This is because, for Wittgenstein, the fundamentality of ethics entails that ethics is possible even if "there is no living being but myself" (NB, 79). However, while treating the other as the source of absolute value, originally enacted by the relation to the other, ethics would obligate me absolutely even if I did not interact with others (Levinas 1998a, $53)$.

The quoted passage highlights another fundamental feature of Levinas's ethics, namely, that the ethical obligation is absolute and without recompense. Ethics is neither measured by its results, nor grounded in any end. If ethics were thus grounded, then my responsibility would be "in calculations of deficits and compensations, in cost accounting. It would be subordinated to thought" (Levinas 2003a, 27). Here, "thought" indicates aboutness, i.e., an intentional relation to objects, states of affairs [Sachverhalt], or empirical facts as objects of knowledge that are always mediated by language as the "Said" (See Levinas 1969, 69, 210; Levinas 1991, 47). ${ }^{12}$ As such, 
"thought" evokes a call for explanation and rational justification. But for Levinas, ethics is more fundamental than rational justification. While the other person is, in one sense, a contingent object of thought, my ethical orientation towards her treats her as absolute. The ethical relation between the subject and the other conditions the possibility of sense and value, and by doing so gives the other a transcendental rather than empirical status. In our reading, Levinas's term "face" [visage] points to the other in the latter, transcendental capacity. (Levinas 1969, 202; Levinas 1998a, 111-112; Levinas 2000, 185-189.)

As indicated by his criticism of the Hegelian historicist view, Levinas contrasts the ethical demand with natural and historical facts. According to Levinas, Hegel takes the value of the other to be determined by the position she occupies in a systematic conceptual whole to which she belongs, namely, the historical unfolding of the Spirit. Levinas writes: "Philosophers have ended up worrying about the meaning of history in a way a shipping company worries about weather forecasts. Thought no longer dares take flight unless it can fly straight to the haven of victory." (Levinas 1990, 226.) By contrast to Hegel, Levinas takes history to be valueneutral and incapable of providing a standard of valuation: "nothing, no event in history can judge a conscience" (ibid., 23). Valuation presupposes a distinction and "discord between events and the good", unavailable for the Hegelian view (Levinas 1969, 246; see Batnitzky 2006, 78). Moreover, by collapsing the distinction between historical events and value, the Hegelian view promises a (theodical) victory, whereas for Levinas the ethical life cannot be based on promises. For just like Wittgenstein, Levinas assumes that the ethical obligates the subject unconditionally, without a promise or hope of a reward.

For Levinas, the standard of valuation is the ethical obligation itself (Levinas 2003a, 29-38). And the only available seat for this standard "is a free being who judges history instead 
of being judged by it." (Levinas 1997, 227; see Levinas 1969, 240-247.) This is to say that the obligation is always presented to the individual subject, to me that is. In accordance with Kant and Wittgenstein, Levinas rejects the Cartesian conception of a substantial subject: "There is nothing that is named $I$. The I is said by him that speaks." (Levinas 1991, 56.) Yet, Levinas argues that the subject is individuated by the unnegotiable and unshareable ethical responsibility. The relevant $I$ is not an object, but that unique ethical subject on whose shoulders the entire moral weight of the world rests: "The self is a sub-jectum; it is under the weight of the universe, responsible for everything." (Levinas 1991, 116; see ibid., 112, 114; Morgan 2007, 155-160, 219-227; Drabinski 2001, 167-219; Salanskis 2015, 21-27.)

Levinas's account of the subject as individuated by responsibility and as free to judge history resonates with Wittgenstein's words: "What has history to do with me, mine is the first and only world. [...] I have to judge the world, to measure things." (NB, 82.) While Wittgenstein's concern is not related to Hegelianism, the core idea for both Levinas and Wittgenstein is that ethics forces the subject to take a personal stance on the world or on the other as that which is presented to the subject as an ethical challenge. For Levinas, the person who responds to the absolute ethical demand is liberated from her contingent surroundings and is able to see herself as unique (Levinas 1991, 121-129). Similarly, Wittgenstein connects ethics with the unique position of the subject: "Only from the consciousness of the uniqueness of my life arises religion - science - and art" (NB, 79).

For Wittgenstein, psychological states are irrelevant for ethics because they are facts and as such contingent. Similarly, Levinas rejects moral sentimentalism because empirical states can never meet the absoluteness of the ethical demand: "my substitution to the other is the trope of a sense that does not belong to the empirical order of psychological events, an Einfühlung or a 
compassion which, by virtue of this sense, signify." (Levinas 1991, 125, translation modified.) As noted by Chalier, Levinas's reasons for criticizing the sentimentalist tradition are Kantian: both Kant and Levinas “are reluctant to trust efforts to defend man's spontaneous compassion or sympathy. Nothing is less sure, they say, and no ethics can rely on the partiality of individual impulses, even generous ones, without running the risk of injustice.” (Chalier 2002, 25; cf. CPrR 5:118) While pragmatically useful in relating to others, compassion and love cannot ground moral obligation given their partiality and contingency. This point underscores the nature of the ethical relation: my relation to the other is not founded on empirical sentiments or interactions but on a more fundamental responsibility that alone can give those facts their value.

While Levinas does not approach the distinction between facts and value in explicitly Kantian terms, his position is clearly indebted to Kant. By reference to the distinction between being and the ethical, between ontology and ethics, Levinas writes:

We shall retain from Kantianism a sense that is not dictated by a relationship with being. It is not accidental that this reference comes from morality, which to be sure, is said to be rational on account of universality of the maxim. It is not accidental that this way of thinking about meaning beyond being is the corollary of an ethics. (Levinas 2000, 65, translation modified; see also ibid., 57-77 and Levinas 1991, 129.)

This remark expresses Levinas's commitment to the transcendentality of ethics in the previously discussed Kantian sense of treating the necessary condition for the sense of life. ${ }^{13}$ Ethics is transcendental, "provided that 'transcendental' signifies a certain priority: except that ethics is before ontology [...] It is a transcendentalism that begins with ethics" (Levinas 1998b, 90). ${ }^{14}$ 
Given that ethics precedes ontology, no inquiry into the nature of things will give us an account of the ethical obligation (Levinas 1969, 42-48; see also Levinas 1985, 96-97; Levinas 1991, 99109; Levinas 1998a, 152-171; Levinas 2000, 181-182; Fagenblatt 2004, 14-20). Echoing the Kantian reflective turn from facts to their possibility, Levinas states: "My task does not consist in constructing ethics; I only try to find its meaning” (Levinas 1985, 90).

Finally, for Levinas, the transcendentality of ethics means that ethics is "ineffable" or "unsayable"; it escapes the Said (cf. Levinas 1991, 7, 44). ${ }^{15}$ If we try to "say" the ethical, we will only end up providing reasons for the ethical obligation; and doing that will inevitably distort the nature of the ethical as a non-conditioned condition for the sense of life. To ask for the grounds of my obligation is to already step out of the ethical relation. Instead of being grounded in reason, reason itself is grounded in the ethical: the subject's relation to the world is primarily ethical, where the ethical conditions also theoretical knowledge. Hence, even though he endorses the Kantian view of the primacy of practical philosophy, Levinas rejects Kant's attempt to provide a rational foundation for morality. According to him, by providing theoretical reasons for the obligation, Kant ends up "saying the unsayable". Interestingly, however, Levinas acknowledges that expressing "the unsayable" may turn out to be necessary in philosophy, even if this is always a "betrayal of the unsayable" (Levinas 1991, 162). - A betrayal not unlike that we find in the Tractatus that fails to comply with the method of saying "nothing except what can be said" (TLP 6.53).

\section{Wittgenstein: seeing the world from the right perspective}

Wittgenstein's statements about the independence of the world of the will, the location of value in the willing subject not part of the world, and the contingency and resulting lack of value of 
facts leave slim resources to make sense of the will's ethical relation to the world. In the Notebooks, Wittgenstein struggles with the apparent gulf between the will and the world:

Is it possible to will good, to will evil, and not to will?

Or is only he happy who does not will?

“To love one's neighbor" would mean to will!

But can one want and yet not be unhappy if the want does not attain fulfilment? (And this possibility always exists.)

Is it, according to common conceptions, good to want nothing for one's neighbor, neither good nor evil?

And yet in a certain sense it seems that not wanting is the only good. [...]

Here everything seems to turn, so to speak, on how one wants.

It seems one can't say anything more than: Live happily! (NB, 77-78.)

As the passage shows, rather than explaining the good will by establishing a connection between the will and the world by reference to an expressible ethical principle that determines what facts may or may not be in conformity with it, Wittgenstein focuses solely on the internal character subject's will. And instead of characterizing the will as a power to influence the world, he writes, "The will is an attitude of the subject to the world" (NB, 87).

In the Tractatus, Wittgenstein writes about the ethical attitude to the world as follows: "To view the world sub specie aeterni is to view it as a whole - a limited whole. Feeling of the world as a limited whole - it is this that is mystical." (TLP 6.45). Interestingly, in Kant's philosophy, the world as a limited whole is a notion that falls outside the bounds of cognition 
together with the notions of purpose, freedom, and God. However, in the Third Critique Kant argues that there is a non-conceptual yet normative judgment that shows the world-whole as purposive for our moral ends so that the demand of the moral law and nature may appear to be in a harmony. Kant calls this type of judgment reflecting, contrasting it with determining judgments that subsume sensible intuitions under concepts and yield empirical cognition. Rather than grounded in concepts, reflecting judgments are based on a feeling that arises from a disinterested contemplation of the form of the object, where that contemplation is governed by the a priori principle of the power of judgment itself. For Kant, the paradigm example of a merely reflecting, non-conceptual judgment is the judgment of beauty, which does not ascribe properties to its object but instead claims that the form of the object has a necessary relation to one's subjective, disinterested pleasure. Hence, in the Kantian tradition, a judgment based on a feeling may have normative force independently of the realm of conceptual thought. (CPJ 5:179-186, 5:211, 5:236; see CPrR 5:124.)

In accordance with Kant's way of connecting the judgment of beauty and the worldwhole's purposiveness for our moral goals by grounding both in the reflecting power of judgment, Wittgenstein connects aesthetics and ethics by reference to a sub specie aeternitatis attitude. In the Notebooks, he writes: "The work of art is the object seen sub specie aeternitatis; and the good life is the world seen sub specie aeternitatis. This is the connection between art and ethics" (NB, 83). Wittgenstein describes the perspective shared by ethics and aesthetics as one that sees the world or an ordinary object - not in time and space - but "together with time and space" $(\mathrm{NB}, 83)$. His example is the experience of contemplating a stove: 
If I have been contemplating the stove, and then am told: but now all you know is the stove, my result does indeed seem trivial. For this represents the matter as if I had studied the stove as one among the many things in the world. But if I was contemplating the stove it was my world, and everything else colourless by contrast with it. (NB, 83.)

What renders the stove meaningful for the contemplating subject is the form of the perspective that underlies both ethics and aesthetics. ${ }^{16}$ In addition to setting aside knowledge of the stove as a complex fact in the world, an integral feature of the perspective is the endorsement of the subject's inability to influence facts. The perspective is, as Wittgenstein writes, without fear and hope; i.e., fear of death and suffering as well as hope of acquiring the things for which one wishes. In short, the attitude characteristic of valuation takes a form of disinterested contemplation of an object or the world as a whole. (NB, 73-75.) The first instance, i.e., seeing the stove as a "my world", as a limited whole "together with space and time", thus fits Kant's account of pure aesthetic judgments. The second instance takes the whole world, i.e. one's life, as the object of similar contemplation, thereby showing it as purposive (cf. TLP 5.621; NB 73).

It should not come as a surprise, then, that in the Tractatus Wittgenstein states that "ethics and aesthetics are one" (TLP 6.421). If read against the background of the evidence of the Notebooks, ethics and aesthetics are one in that both aesthetic and ethical "judgments" (seeing the stove as one's world, seeing the world as a limited whole) spring from the same disinterested perspective of contemplation, capable of rendering the subject's world meaningful or happy:

Is it the essence of the artistic way of looking at things, that it looks at the world with a happy eye? 
Life is grave, art is gay.

For there is certainly something in the conception that the end of art is the beautiful.

And the beautiful is what makes happy. (NB, 86.)

Especially these final remarks may give the impression of moral nihilism, where in the face of the lack of value in the world, one ought to just enjoy pretty things and savor the pleasurable experiences drawn from them. Such a reading would be misguided due to a failure to acknowledge the absoluteness of ethics as one of Wittgenstein's unquestionable starting points. It would also fail to do justice to Wittgenstein's claim of the transcendentality of ethics, given that the pleasures thus understood would be mere contingent, empirical events. But if Wittgenstein's remarks on value are read against the Kantian background, as we have done, then the sub specie aeternitatis attitude is no less normative than a conceptually grounded thought. After all, the entire argument of Kant's analytic of the beautiful is aimed at showing that, while the judgment of beauty is based on a subjective feeling of pleasure, it nevertheless succeeds in making a justified claim to necessity. This is because it relies on the a priori principle of formal purposiveness as the principle that allows us to see actions, objects, states of mind, and even the world-whole as purposive (CPJ 5:220).

What we are suggesting, then, is that Wittgenstein's answer to the problem of life, i.e., the problem of seeing one's life as meaningful or purposive in spite of its objective lack of meaning or purpose, relies on a similar idea of formal purposiveness. The purposiveness in question is not an objective property of the facts of world that could be expressed by propositions, but the formal condition for the possibility of seeing sense or purpose in that world 
and as such as ineffable as logical form grounding meaningful language. In the ethical attitude, the world is judged not by reference to concepts but by reference to a feeling, where the feeling arises from a disinterested and non-conceptual contemplation of the form of the world as a whole. In this respect, the subject's ethical relation to the word resembles Kant's account of the judgment of beauty that judges the purposiveness of the object by relating the representation of the form of the object to the subject's feeling rather than by means of concepts to the object itself (CPJ 5:203).

Recall Wittgenstein's original question, "What do I know about God and the purpose of life?" (NB, 72). He responds as follows:

[...] Dostoievsky is right when he says that the man who is happy is fulfilling the purpose of existence.

Or again we could say that the man is fulfilling the purpose of existence who no longer need to have any purpose except to live. That is to say, who is content. (NB, 73; see TLP 6.521.)

When the subject adopts the disinterested, contemplative perspective on the world, she does not look at the world as an aggregate of contingent facts without sense and purpose but sees the very same totality of facts from a perspective that shows it as a limited whole and as such as meaningful or purposive $(\mathrm{NB}, 74)$. Seeing the world as a limited whole brings the subject's will into harmony with the world and thereby renders the subject's world a "happy world" (TLP 6.43). The happiness in question is not factual, empirical happiness, but mere harmony between the transcendental will of the subject and the world given to her: 
What is the objective mark of the happy, harmonious life? Here it is again clear that there cannot be any such mark, that could be described.

This mark cannot be a physical one but only a metaphysical one, a transcendental one. (NB, 78.)

So given that the requirement of empirical content for the possibility meaningful language blocks the route to a conceptual explanation of the grounds of that harmony, Wittgenstein turns to aesthetic judgment in his elucidation of the harmony between the will and the world. In doing so, he relies on a notion of aesthetic judgment that resembles Kant's account of the judgment of beauty as a non-conceptual judgment that judges its object by feeling and yet succeeds in making a justified claim to necessity. Most importantly, in its appeal to the aesthetic judgment, Wittgenstein's resolution of the original tension between the world of facts and the sense of the world, characteristic of the Tractatus's position, echoes Kant's strategy in his attempt to build a bridge between nature and freedom by reference to the judgment of beauty.

Now, one may ask whether the solution succeeds in doing justice to Wittgenstein's unquestioned starting assumption about the absoluteness of ethics, which ruled out the possibility of expressing ethical laws in meaningful language. That Wittgenstein himself thinks that it does is revealed by his remark:

And if I now ask myself: But why should I live happily, then this of itself seems to me to be a tautological question; the happy life seems to be justified, of itself, it seems that it $i$ the only right life (NB, 78). 
The appeal to the notion of a tautology here is significant. While not a tautology in the technical sense of the Tractatus, indicating necessary truth at the expense of empirical content, the claim that I ought to live happily, i.e., adopt such an attitude that will establish agreement between my will and the world, seems to have the kind of necessity that Kant attached to his a priori principles. But instead of taking his lead from the conceptually grounded necessity, Wittgenstein places the normative pull of ethics on the form of the feeling that aesthetics and ethics, in his view, share.

\section{Levinas: The Sense of Being}

The absence of the other from Wittgenstein's early view should not mask the structural similarity between Wittgenstein's and Levinas's views of ethics as orienting the subject towards something presented as a challenge. Wittgenstein's ethical subject faces the world as "something that is already there" (NB, 74). For Wittgenstein, the mere existence of the world is not sufficient for ethics, for it is only in my relation to the world - when I see the world as an "aesthetic miracle" that the possibility value arises (NB, 79, 86, see TLP 6.44). For Levinas, the subject faces another person. But in the ethical relation one does not approach the other person as a mere empirical object. While the other is also an empirical being, as the source of absolute value she assumes a transcendental status: "But the epiphany of the Other bears its own significance, independent of the signification received from the world. The Other not only comes to us from a context but signifies itself, without that mediation." (Levinas 2003a, 31; see also Levinas 1969, 177-178.) 
Why, then, should I take the moral demand upon myself? According to Levinas, "No one is good voluntarily" (Levinas 1991, 11). As natural beings, we are disposed to prioritizing our own life over that of others: "A being is something that is attached to being, to its own being. That is Darwin's idea. The being of animals is struggle for life. A struggle for life without ethics." (Levinas 2003b, 172.) This is what Levinas calls the "Law of Being", which is the defining mode of being for all natural entities, guided by interest. However, if the human life is nothing but individualistic self-affirmation driven by interest, then it is a constant state of struggle and war without sense. However, Levinas writes, "with the appearance of the human and this my whole philosophy - there is something more important than my life, and that is the life of the other" (Levinas 2003b, 172).

In Totalité et Infini, Levinas defines ethics as being put into question by the other, which gives rise to the moral conscience. One is called to justify one's own freedom, which is limited by the other person:

Moral conscience welcomes the Other. It is the revelation of a resistance to my powers that does not counter them as a greater force, but calls in question the naive right of my powers, my glorious spontaneity as a living being. Morality begins when freedom, instead of being justified by itself, feels itself to be arbitrary and violent. (Levinas 1969, 84.)

Being called into question arouses a consciousness of "guilt" insofar I realize that I am not an innocent spontaneity, but that in my natural concern for my own being I have already taken space away from others. I am always already a possible usurper. (Levinas 1969, 83.) 
For Levinas, the acknowledgement of one's guilt means "awakening" or "sobering up" (Levinas 1998b, 15-32). Especially in his notes from 1950s and 1960s, Levinas calls such awakening an ethical attitude (see Levinas $2009,459,476$ ). The awakening indicates a turning away from selfishness to "ethical consciousness", to seeing my world as a world conditioned by the other and hence as something to be shared, to be given to others. Hence, to sober up is to realize that I am driven by an illusory sense of freedom and readily fall into a comforting yet deceptive state of "good conscience". Levinas speaks of the vigilant I, awakened by the vulnerability and mortality of my neighbor, giving rise to the acknowledgment of one's responsibility for the other. The ethical awakening thus takes the form of embracing a specific attitude towards other human beings (see e.g. Petitdemange 2003, 331).

The unconditioned ethical obligation to give from one's own without hope of a recompense should guide our everyday dealings, whether theoretical, practical, or political. Hence, when Levinas claims that ethics is a fundamental dimension of human life, he is not only making a descriptive phenomenological observation, but a normative one. Ethics as the transcendental condition for the possibility of sense must guide and serve as a standard. Acknowledgement of the endless responsibility, Levinas writes, "justifies being by that which assures it" (Levinas 1998b, 177). That ethics "justifies" being means that it is the standard against which being is measured; that ethics "assures being" means that it is the ground of being. Accordingly, to be ethically awakened is to acknowledge the fundamentality of the ethical and to treat it as a standard, which is precisely what the ethical attitude means. Levinas writes:

I am not saying that the human being is a saint, I'm saying that he or she is the one who has understood that holiness is indisputable $[\ldots]$ the ideal of holiness is what humanity 
has introduced into being. An ideal of holiness contrary to the laws of being. (Levinas 1998a, 109-114.)

So for Levinas, ethics is unreasonable and "disinterested" (See Levinas 2003b, 172; Levinas 1991, 8). Ethics is unreasonable because it is contrary to my natural mode of being and because it requires everything, including self-sacrifice. It is disinterested because the subject is forced to set aside her personal interests, to "always empty oneself anew" (Levinas 1991, 92). One might think that the centrality of the other and the demand to care for the other introduces an interest into Levinas's picture. However, insofar as there is an interest, it does not concern my own being: "The fear for another as a fear for the death of a neighbor is my fear but it is in no wise a fear for me" (Levinas 1998b, 176). Rather, to embrace the ethical, disinterested attitude is to see the world as something I must give to the other without a promise of recompense. And to see the world in this way is to see it as having sense.

Both Levinas and Wittgenstein thus connect ethics with a way of seeing the world. In conversation with Friedrich Weismann, Wittgenstein reportedly noted that people have felt a connection between ethics and the existence of the world and expressed the connection as follows: "God the Father created the world, while God the Son (or the Word proceeding from God) is the ethical" (Waismann 1965, 16). Levinas addresses the connection in one of his Talmudic Readings, discussing a passage from the Tractate Shabbat (88a-88b) that asks, why the Earth trembled in fear and then become calm when the Law was given (cf. Psalm 76:9). Levinas locates the answer in Rash Lakish's interpretation of Genesis 1:31. According to Rash Lakish, the earth was afraid because its fate was decided: in creation, God made a covenant with the world, namely, that as long as His Will is fulfilled, the world will exist. Hence, the calm was due 
to the consent given by Israel to follow the Law. For Levinas, this means that the ethical (the Law) is the sustaining principle of the whole of creation; that is, the ethical is the condition of the world (Levinas 1969, 204, 212).

For Levinas, "The world is here so that ethical order has the possibility of being fulfilled. The act by which the Israelites accept the Torah is the act which gives meaning to reality. To refuse the Torah is to bring being back to nothingness." (Levinas 1994, 41.) This means that evil is nothing but a chaotic state meaninglessness devoid of value. The choice given by God between Law or nothingness becomes in Levinas's work a choice between sense and senselessness, between ethics and mere being. To consent to the ethical demand, then, is to give priority to ethics over being, to acknowledge absolute value, which is irreducible to how the world is and which gives sense to being itself. As Levinas writes: "Being has sense. The sense of being, the sense of creation - is the realization of the Torah [ethics]." (ibid., 41; translation modified.) But it is not enough for Levinas to merely recognize the priority of the ethical. I must also realize my responsibility by keeping the world from falling into chaos. As God brought order into to primal chaos (tohu-va-bohu) through his creative action, it is my responsibility to continue to enact the work of creation by maintaining the ethical order. And this just is the task of ensuring that the world has sense.

The ethical attitude is to see the world in the right way, as normatively oriented from the start, governed by an ethical order whose fulfillment guarantees the world sense. In this respect, Levinas comes close to Wittgenstein, for whom ethics sees the world sub specie aeterni, as a limited whole and as such meaningful. However, by contrast to Wittgenstein, whose description of the view from eternity has an aesthetic, contemplative character, for Levinas, the perspective of eternity is the perspective of the ethical obligation to and for the other. Importantly, neither 
Wittgenstein nor Levinas refer to eternity as a transcendent realm. Levinas commends Kant on the idea that orientation in thinking is to direct oneself towards that which exceeds the limits of knowledge, towards a beyond which cannot be said to be. However, as ethics requires renouncing any recompense, Levinas rejects Kant's conception of the highest good as saying too much. He asks, "Are we entering a moment in history in which the good must be loved without promises [...] a time when the only right to reward would be not to expect one" (Levinas 1999, 109). In this respect Levinas, like Wittgenstein, takes ethics to contain its own reward and connects that reward with the sense of life (Levinas 1998b, 131-134; TLP 6.422; see Plant 2005, 119-120).

\section{Conclusion}

We have argued that both Wittgenstein and Levinas ought to be read as endorsing the divide between the domains of nature and freedom, which lies at the core of Kant's practical philosophy. For both, the relevant contrast lies between the world of facts and the sense of that world. Moreover, both respond to the philosophical challenge arising from the divide by appealing, in part, to resources provided by Kant's philosophy. The most important affinity between Wittgenstein and Levinas is that, in spite of granting a need for a transcendental foundation for ethics, they reject the possibility of a conceptual or rational explication of that foundation. Any foundation for ethics - whether given by reference to facts or to a conceptually expressible principle - will only make ethics conditional. Instead, for both, ethics is a condition of the world. The absolute ethical obligation, which the subject finds in herself independently of the facts of the world, is the necessary condition for the possibility of the world's sense. 
Moreover, Wittgenstein and Levinas come together in denying the availability of a reward for the ethical orientation - or rather, as both claim, that the reward resides in the ethical relation itself. This is to say that both Wittgenstein and Levinas take Kant's initial confirmation of a break between morality and its reward reflecting the gulf between nature and morality to its extreme. Accordingly, the hope of a just distribution of happiness according to moral worth that Kant presents as grounded in practical reason, becomes extremely thin: for the subject, the ethical demand holds no other promise but her ability to transcend the contingency of the world and see it as having sense - a promise that still has a characteristically Kantian ring. ${ }^{17}$

\section{References}

Allison, Henry (1990) Kant's Theory of Freedom. Cambridge: Cambridge University Press.

Appelqvist, Hanne (2013) "Why does Wittgenstein say that ethics and aesthetics are one and the same?", in P. Sullivan and M. Potter (eds), Wittgenstein's Tractatus: History and Interpretation. Oxford: Oxford University Press, 40-58.

Appelqvist, Hanne (2016) “On Wittgenstein’s Kantian Solution of the Problem of Philosophy”, The British Journal for the History of Philosophy 24 (4), 697-719.

Appelqvist, Hanne (2018) "Wittgenstein on the Grounds of Religious Faith: A Kantian Proposal", The European Journal of Philosophy 26 (3), 1026-1040. 
Batnitzky, Leora (2006) Leo Strauss and Emmanuel Levinas: Philosophy and Politics of Revelation. Cambridge: Cambridge University Press.

Basterra, Gabriela (2015) The Subject of Freedom: Kant, Levinas. New York: Fordham University Press.

Bernasconi, Robert (2005) "Rereading Totality and Infinity", in C. E. Katz (ed), Emmanuel Levinas: Critical Assessment of Leading Philosophers. London: Routledge, 32-44.

de Boer, Theodore (1997) The Rationality of Transcendence: Studies in the Philosophy of Emmanuel Levinas. Amsterdam: J.C. Gieben.

Chalier, Catherine (2002) What Ought I Do? Translated by J. M. Todd. Ithaca and London: Cornell University Press.

Cohen, Richard (2010) Levinasian Meditations: Ethics, Philosophy, and Religion. Pittsburgh: Duquesne University Press.

Drabinski, John E. (2001) Sensibility and Singularity. New York: SUNY Press.

Fagenblatt, Michael (2004) "Lacking All Interest: Levinas, Leibowitz, and the Pure Practice of Religion", The Harvard Theological Review 97 (1), 1-32. 
Franck, Didier (2008) L'un-pour-l'autre : Levinas et signification. Paris: PUF.

Frangeskou, Adonis (2017) Levinas, Kant and the Problematic of Temporality. London: Palgrave Macmillan.

Glock, Hans-Johann (1992) "Cambridge, Jena or Vienna? The Roots of the Tractatus", Ratio 5 (1), 1-23.

Glock, Hans-Johann (1997) “Kant and Wittgenstein: Philosophy, Necessity and Representation”, International Journal of Philosophical Studies, 5 (2): 285-305.

Glock, Hans-Johann (1999) "Schopenhauer and Wittgenstein: Language as Representation and Will”, in C. Janaway (ed), The Cambridge Companion to Schopenhauer. Cambridge: Cambridge University Press, 422-458.

Hacker, Peter (1986) Insight and Illusion. Revised edition. Oxford: Clarendon Press.

Kannisto, Heikki (1986) Thoughts and Their Subject: A Study of Wittgenstein's Tractatus. Acta Philosophica Fennica Vol 40. Helsinki: The Philosophical Society of Finland.

Kant, Immanuel (2000) Critique of the Power of Judgment (CPJ). Edited by P. Guyer, translated by P. Guyer \& E. Matthews. Cambridge: Cambridge University Press. 
Kant, Immanuel (1998) Critique of Pure Reason (CPR). Edited and translated by P. Guyer and A. Wood. Cambridge: Cambridge University Press.

Kant, Immanuel (1997) Critique of Practical Reason (CPrR). Edited and translated by M. Gregor. Cambridge: Cambridge University Press.

Kant, Immanuel (1997) Groundwork of the Metaphysics of Morals (G). Edited and translated by M. Gregor. Cambridge: Cambridge University Press.

Levinas, Emmanuel (1969) Totality and Infinity. Translated by A. Lingis. Pittsburgh: Duquesne University Press.

Levinas, Emmanuel (1985) Ethics and Infinity. Translated by R. A. Cohen. Pittsburgh: Duqesne University Press.

Levinas, Emmanuel (1990) Difficult Freedom: Essays on Judaism. Translated by S. Hand. Baltimore: John Hopkins University Press.

Levinas, Emmanuel (1991) Otherwise than Being or Beyond Essence. Translated by A. Lingis. Dordrecht: Kluwer Academic Publisher. 
Levinas, Emmanuel (1994) Nine Talmudic Readings. Translated by A. Aronowicz. Bloomington \& Indianapolis: Indiana University Press.

Levinas, Emmanuel (1997) Difficult Freedom. Baltimore: The John Hopkins University Press.

Levinas, Emmanuel (1998a) Entre Nous. Translated by M. B. Smith and B. Hershav. New York: Columbia University Press.

Levinas, Emmanuel (1998b) The God Who Comes to Mind. Translated by B. Bergo. Stanford: Stanford University Press.

Levinas, Emmanuel (1999) Alterity and Transcendence. Translated by M. B. Smith. London: The Athlone Press.

Levinas, Emmanuel (2000) God, Death, and Time. Translated by B. Bergo. Stanford: Stanford University Press.

Levinas, Emmanuel (2003a) Humanism of the Other. Translated by N. Poller. Chicago: Univeristy of Illioin Press.

Levinas, Emmanuel (2003b) "Paradox of Morality: Interview with Emmanuel Levinas", in Robert Bernasconi and David Wood (eds), Provocation of Levinas: Rethinking the Other. London: Routledge, 168-180. 
Levinas, Emmanuel (2008) “The Contemporary Relevance of Maimonides” (translated by M. Fagenblatt), Journal of Jewish Thought and Philosophy 16 (1), 91-94.

Levinas, Emmanuel (2009) Carnets de captivité et autres inédits. Paris: Éditions Grasset \& Fasquelle.

Moore, A. W. (1987) "Beauty in the Transcendental Idealism of Kant and Wittgenstein", British Journal of Aesthetics 27 (2), 129-137.

Moore, A. W. (2013) “Was the Author of the Tractatus a Transcendental Idealist?”, in P. Sullivan and M. Potter (eds), Wittgenstein's Tractatus: History and Interpretation. Oxford: Oxford University Press, 239-255.

Morgan, Michael (2007) Discovering Levinas. Cambridge: Cambridge University Press.

Øvergaard, Soren (2007) "The Ethical Residue of Language in Levinas and Early Wittgenstein", Philosophy and Social Criticism 33 (2), 223-249.

Pears, David (1987) The False Prison Vol I. Oxford: Clarendon Press.

Petitdemange, Guy (2003) Philosophes et philosophies du XXe siècle. Le Seuil: Paris.

Plant, Bob (2005) Wittgenstein and Levinas. Ethical and Religious Thought. London: Routledge. 
Salanskis, Jean-Michel (2015) Le concret et l'idéal : Levinas vivant III. Paris: Klincksieck.

Stenius, Erik (1960) Wittgenstein's Tractatus: A Critical Study of its Main Lines of Thought. Oxford: Basil Blackwell.

Sullivan, Peter (1996) “The 'Truth' in Solipsism, and Wittgenstein's Rejection of the A Priori”, European Journal of Philosophy 4, 195-219.

Shaw, Joshua (2008) Emmanuel Levinas on the Priority of Ethics. New York: Cambria Press.

Waismann, Friedrich (1965) “Notes on Talks with Wittgenstein”, The Philosophical Review, $74: 1,12-16$.

\section{Notes}

${ }^{1}$ For Kant, the moral law is the principle of universalizability of one's maxim: insofar as something is a reason for me, it ought to be a reason for everyone else as well, for otherwise it would not make sense to talk about reasons in the first place. Accordingly, the universalizability principle is a principle constitutive of agency understood as responsiveness to reasons. (G 4:421, see Allison 1990, 204-205.)

${ }^{2}$ Our goal is not to defend a historical claim of actual influence, but to indicate those substantial affinities between Wittgenstein and Levinas that we see as fruitfully illuminated against the 
background of Kant's philosophy. Our argument relies on the Kantian interpretation of the philosophical goals of the Tractatus defended and developed by, e.g., Stenius 1960, Kannisto 1986, Glock 1992 and 1997, Moore 2013, and Appelqvist 2013, 2016, and 2018. The most accessible account of the philosophical connections between Levinas and Kant is Chalier 2002; see also Cohen 2010; Basterra 2015; Frangeskou 2017.

${ }^{3}$ Our argument relies on the material of Notebooks 1914-1916 and Wittgenstein's 1929 "Lecture on Ethics". While we acknowledge the limitations of this approach, in our view the Tractatus's scarce remarks on value can be understood only if read against the background of Wittgenstein's more substantial discussions on the theme.

${ }^{4}$ On the Kantianism of Wittgenstein's early view of the world of knowledge and ethics, see Moore 1987. For comparisons between Levinas and Wittgenstein from the viewpoint of the resolute reading of Wittgenstein's early philosophy, see, e.g., Øvergaard 2007, Morgan 2007. ${ }^{5}$ Here, we rely on Kannisto's interpretation according to which even false propositions have been projected onto a specific place in reality (see TLP 3.12; Kannisto 1986, 66-68).

${ }^{6}$ On the transcendentality of logic in the Tractatus, see Kannisto 1986, Glock 1992, and Appelqvist 2016.

${ }^{7}$ The identification of the world and life is unsurprising if the Tractatus is read as a work committed to transcendental idealism. In that framework, the formal unity of the world and thought is grounded in the metaphysical subject as the vehicle of the form shared by thought and reality. Such a view may be seen as underlying Wittgenstein's remark: "The world is my world: this is manifest in the fact that the limits of language (of that language which alone I understand) mean the limits of $m y$ world" (TLP 5.62). 
${ }^{8}$ Wittgenstein's reference to the world's purpose resonates with Kant's terminology in the Critique of the Power of Judgment. There, Kant introduces the distinction between the determining (cognitive) and the reflecting (aesthetic) perspectives on the world: the first sees the world as an aggregate of facts, the latter sees objects, actions, states of mind, and the world as a purposive (CPJ 5:179-181, 20:217-218). While the latter perspective does not amount to knowledge, Kant takes it to strengthen one's hope in highest good, namely, in God's existence and the purposiveness of the world for our moral efforts.

${ }^{9}$ In terms of their relative and absolute normative forces, Wittgenstein's contrast between relative and absolute value judgments corresponds to Kant's contrast between hypothetical and categorical imperatives (see G 4:414).

${ }^{10}$ This phrasing is distinctly Schopenhauerian, raising the contrast between Will and Idea (see Hacker 1986, 87-90). At the same time, Wittgenstein's position differs from the Schopenhauerian view in that, while for Schopenhauer all willing is problematic, Wittgenstein endorses the Kantian distinction between good and bad willing. Most importantly, as noted by Glock, Schopenhauer's influence does not help in explaining Wittgenstein's characteristically Kantian concern with the necessary, formal conditions of experiencing or depicting reality (see Glock 1999, 425-432).

${ }^{11}$ Accordingly, Wittgenstein evocation of happiness as a manifestation of good will does not directly conflict with Kant's rejection of happiness as the guiding principle of morality (G 4:417-419; 442). Given the contemplative quality of the subject's attitude to the world, happiness as "agreement" or "harmony" is more akin to the disinterested pleasure Kant identifies as the experience characteristic of a judgment of beauty (CPJ 5:211). 
${ }^{12}$ In Levinas's terminology, the "Said" is the register of intentional thought. Narrowly, the Said is any proposition that says something about the world and inner worldly objects. More broadly, the Said is the register of all that can be asserted and thought insofar as this is taken to include the meaning-constitutive intentional relation between the subject and the world. By contrast, the "Saying" is the immediate openness toward the other. It is not yet linguistic and it is irreducible to the Said. The Saying does not point to a transcendent domain outside the phenomenal world, but to my concrete relation with another. According to Levinas, the Western philosophical enterprise has been exclusively interested in the Said without willingness or ability to "think" the Saying (the unsayable, the ineffable). Levinas's own project is to uncover the Saying, covered up by the Said (this is called "reduction"). Yet, pure Saying, as unsayable, cannot be said, thus making the attempted reduction a never-ending task. When the Saying is described, it is introduced in to the register of the Said. Thus, the philosopher's task is to continuously "unsay" that which is said about the Saying. (See Levinas 1991, 43-45, 181; Morgan 2007, 300-323; Franck 2008, 213-220.)

${ }^{13}$ Following Morgan 2007, we read Levinas as committed to transcendentalism in the sense in which transcendentality refers to the necessary conditions for the possibility of different types of judgments. Alluding to Kant's philosophy in his 1935 essay on the philosophical strength of Maimonides's thought, Levinas writes: "For the first time, and with luminous lucidity, Maimonides separated the laws of a thinking that takes the world as an object from principles of thought relating to the conditions of the world. For the first time he put a stop to the impulse of reason to apply notions borrowed from the world to that which is beyond the world. For the first time he glimpsed what one calls, six centuries later, the critique of pure reason." (Levinas 2008, 
94). For criticisms of the transcendental reading of Levinas, see Bernasconi 2005; Shaw 2008, $133-176$.

${ }^{14}$ For transcendental readings of Levinas, see de Boer 1997, 1-32; Morgan 2007; and Salanskis 2015, 9-43.

${ }^{15}$ While we are not suggesting that Levinas's notions of fact, sayability, and ineffability are identical with those of Wittgenstein, the parallels are striking.

${ }^{16}$ For a more detailed argument to this effect, see Appelqvist 2013.

${ }^{17}$ Parts of the Wittgenstein sections of this paper were presented at the Åbo Academi Philosophy Seminar on March 52018 and at the Stirling Early Analytic Group on April 23 2019. Appelqvist would like to thank the participants of these events, especially Lars Hertzberg, Martin Gustafsson, Colin Johnston, Michael Potter, and Peter Sullivan, for their comments and critical remarks. We would also like to thank Jean-Michel Salanskis, Georges Hansel, and Michael Roubach for their valuable feedback on an earlier version of this paper. 